\title{
NOTES ON THE DIET OF THE CARNIVOROUS MAMMALS OF THE UPPER HENTY RIVER REGION, WESTERN TASMANIA
}

\author{
By Robert J. Taylor
}

(with three tables)

TAYLOR, R.J. 1986 (12:ix): Notes on the diet of the carnivorous mammals of the Upper Henty River region, western Tasmania. Pap. Proc. R. Soc. Tasm. 120: 7-10. https://doi.org/10.26749/rstpp.120.7

ISSN 0080-4703. Department of Zoology, University of Tasmania, Hobart, Tasmania, Australia 7000.

All four of Tasmania's large mammalian carnivores (Sarcophilus harrisii, Dasyurus maculatus, D. viverrinus, Felis catus) occur in the Upper Henty River region, in western Tasmania. A short-term study was undertaken to compare the diet of these species when in sympatry. No data were obtained for $D$. maculatus. The other species overlapped in their use of small mammals. However each species had a major component of the diet ( $S$. harrisii, large mammals; D. viverrinus, invertebrates and plant material; $F$. catus, birds) which was not utilized by the other species and hence substantial competition between them is unlikely. The diet reported by others for $D$. maculatus is similar to that found for $F$. catus. These two species had similar habit preferences and hence it is possible that competition could occur between the native $D$. maculatus and the introduced $F$. catus.

Key Words: Tasmanian carnivores, mammals, diet.

\section{INTRODUCTION}

Three of the larger native carnivorous marsupials (Sarcøhilus harrisii, Dasyurus maculatus and $D$. viverrinus) are still widespread and common throughout much of Tasmania (Green 1973). On the mainland of Australia these species are now either extinct ( $S$. harrisii, $D$. viverrinus) or have suffered a major reduction in their distribution $(D$. maculatus). The insular nature of Tasmania has resulted in the native carnivores being free of any possible competition from foxes (Vulpes vulpes) or dingoes (Canis familiaris) which accompanied the human occupation of the continent. Feral cats (Felis catus), however, were introduced into Tasmania and are now widespread (Hocking \& Guiler 1983).

The diet of $D$. viverrinus has been examined by Green (1967) in the northeast and by Blackhall (1980) and Godsell (1983) in southern Tasmania. Data on the diet of $S$. harrisii are given by Guiler (1970) for three populations in the northeast, south and west of Tasmania, and by Green (1967) for a population in the northeast. All of these studies were conducted in pastoral areas.

A mammal survey conducted in the Upper Henty River region of western Tasmania showed that all four of the carnivores were present (Taylor et al. 1985). Because the area surveyed was remote from human settlement and contained all four species, faecal pellets were collected and used to examine their diet.

\section{STUDY AREA AND METHODS}

The study was conducted in the northern part of the Southwest Conservation Area in the Upper Henty River"region. The area is not settled but mining exploration and selective logging has taken place and a system of roads and tracks is present. The vegetation types occurring in the area are rainforest, wet scrub, eucalypt scrub, sedgeland and alpine. Further details of the study area are given in Taylor et al. (1985).

Trapping was conducted between 6 and 16 November 1983 and between 11 and 21 January 1984. The carnivores were caught in wire mesh traps baited with either day old chicks or meat scraps. Animals were usually kept overnight and their scats collected. Stomach contents from feral cats were also collected. Scats found in the study area which could be confidently identified were also included. Only two of the scats of Felis catus and $D$. viverrinus were not from the animals trapped; however for $S$. harrisii only 5 of the 28 scats analysed were from trapped animals.

Hair in the scats was identified using the methods of Brunner \& Coman (1974) and the key given in Taylor (1985). The hair of Pseudømys higginsi and Mastacemys fuscus is difficult to separate (Taylor 1985). No evidence of $M$. fuscus occurring in the study area was found but $P$. higginsi was widespread and abundant (Taylor et al. 1985). Thus hair found in the scats which could have come from either of these species was classified 
as $P$. higginsi. Any traces of hair from the species whose scat was being examined were not included in the results. Several times the presence of jaw bones in the scat enabled the identification, made on the basis of hair samples, to be corroborated. Birds were identified from feathers. Any traces of chicken feathers or bone from the bait were not included in the results. Invertebrates were identified from exoskeletal remains.

\section{RESULTS}

Dasyurus viverrinus were found to feed on invertebrates, small vertebrates and plant material (table 1). Fifty-three percent of the items identified were invertebrates. Dasyurus maculatus were captured six times and four scats were collected Unfortunately all scats contained only bait.

\section{TABLE 1}

\section{Frequency of Occurrence of Items in Five Scats from Dasyurus viverrinus.}

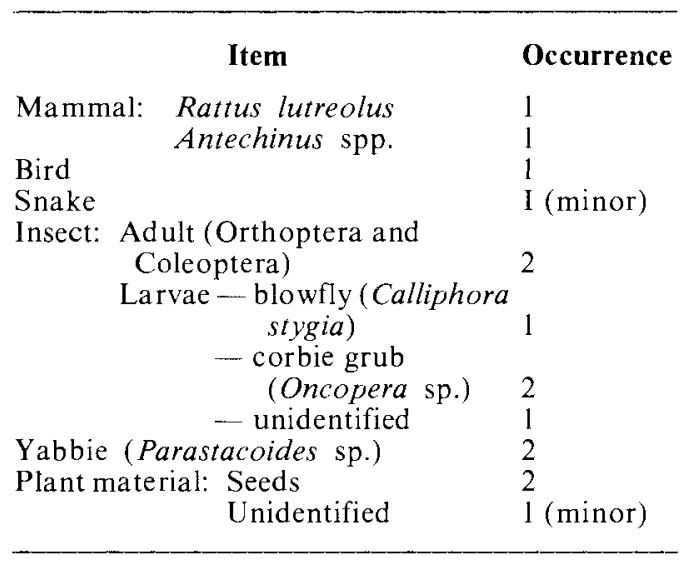

Small mammals and birds made up the bulk of the diet of feral cats (table 2). Much of the hair in the scats of feral cats was finely masticated which made identification difficult. The unidentified small mammal listed in table 2 is based on the size of a tibia found in the scats.

For Sarcophilus harrisii $78 \%$ of the items identified were mammals (table 3 ). All of the nonmammalian items made up a very small proportion of the volume of the scat. Pseudocheirus peregrinus was the most frequently occurring mammal species in the scats. Small species (i.e. rats and mice) made up $45 \%$ of the mammalian items

\section{TABLE 2}

Frequency of Occurrence of Items in Three Stomachs and Ten Scats from Felis Catus.

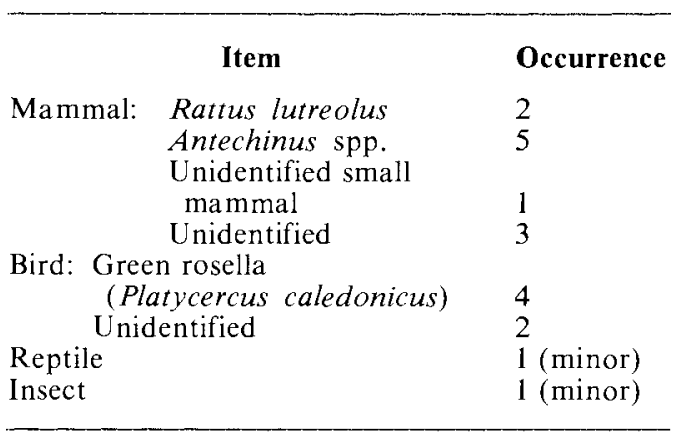

\section{DISCUSSION}

The number of scats obtained during the study was limited. However the data have enabled the categories of food eaten to be elucida ted. Major differences between the species are indicated.

The most extensive study of the diet of $D$. viverrinus was carried out by Godsell (1983) in southern Tasmania. The percentage frequencies of the major items found by Godsell in the scats of $D$. viverrinus were: insect larvae $84 \%$; mature insects $56 \%$; vertebrates $26 \%$; and vegetation $66 \%$. For the vertebrate prey, mammals were more frequently eaten than birds, with the largest mammal eaten being the rabbit (Oryctolagus cuniculus). Godsell (1983) concluded that $D$. viverrinus was an opportunistic predator. The diet of $D$. viverrinus in this study is similar to that found by God sell (1983).

\section{TABLE 3}

Frequency of Occurrence of Items in Twenty-eight Scats from Sarcophilus harrisii.

$\begin{array}{lll} & \text { Item } & \text { Occurrence } \\ \text { Mammal: } & \begin{array}{l}\text { Thylogale billardieri } \\ \text { Pseudocheirus }\end{array} & 5 \\ & \text { peregrinus } & \\ \text { Rattus lutreolus } & 3 \\ \text { Pseudomys higginsi } & 4 \\ & \text { Antechinus spp. } & 6 \\ \text { Bird } & 2 \text { (minor) } \\ \text { Insect: Blowfly larvae (Calliphora } & 2 \text { (minor) } \\ & \text { stygia) } & \text { 1 (minor) } \\ \text { Plant material } & 3 \text { (minor) }\end{array}$


Thus invertebrates, particularly insects, were the most frequently encountered items with small vertebrates and plant material comprising the other items in the diet. Yabbies were not recorded in the other dietary studies of D. viverrinus (Green 1967, Blackhall 1980, Godsell 1983). It is likely that these animals were far more abundant in the present study area. D. viverrinus are known to scavenge when given the opportunity (Godsell 1983). The blowfly larvae found in one of the scats could indicate scavenging in the present study area, however, it is more likely that they were ingested with the bait.

Feral cats fed on small vertebrates. Twothirds of the birds found eaten by feral cats were green rosellas (Platycercus caledonicus). These birds were frequently seen feeding on the tracks in the same vegetation types that feral cats utilized (i.e. rainforest and scrub areas). The presence of green rosellas on the ground, in open areas where they could be easily stalked, would increase the susceptibility of this species to predation in comparison with other birds. Other studies have also found that feral cats feed mainly on small vertebrates, up to the size of the brushtail possum Trichosurus vulpecula (Jones \& Coman 1981, Brunner et al. 1981).

Sarcophilus harrisii has been reported to feed on a wide variety of foods with most of the large and medium-sized prey considered to be scavenged (Green 1967, Guiler 1970). The majority of the food of $S$. harrisii has been found to be mammalian (op. cit.). This is also the case in the present study area. Small mammals, ringtail possums (Pseudocheirus peregrinus) and pademelons (Thylogale billardieri) were found to be eaten by $S$. harrisii. In the pastoral areas, where the diet of $S$. harrisii has previously been examined (Green 1967, Guiler 1970), carrion is abundant due to the presence of domestic stock and native mammals that have been killed on the roads or as pests. $S$. harrisii is considered to be an inept killer that scavenges rather than hunts (Buchmann \& Guiler 1977, Guiler 1983). Because of the isolated nature of the study area, carrion resulting from human activities is likely to be uncommon. Blowfly larvae were found in two scats. One of these was from a trapped animal and could have come from the bait. The other was from a scat picked up in the area; thus some of the items eaten by $S$. harrisii in the study area may be scavenged. However l consider it unlikely that all of their diet could be obtained in this way.

In the Lower Gordon River region Hocking \& Guiler (1983) concluded that $S$. harrisii was confined to areas bordering the major rivers. The density of vegetation may impede prey capture in this region. In the present study area, in contrast to the Lower Gordon River region, roads and tracks are abundant. These are used extensively by $S$. harrisii for movement (Taylor et al. 1985). S. harrisii is probably too slow to run down its prey (Guiler 1983), however the roads could be used for stalking. S. harrisii may be able to closely a pproach animals present on or near roads and hence use the element of surprise to successfully kill their prey. Pademelons were frequently seen feeding along the sides of the roads (Taylor et al. 1985).

The ringtail possum is largely an arboreal species (Thomson \& Owen 1964) and hence its frequency in the diet of $S$. harrisii is surprising. Guiler (1970) found ringtail possum remains in $17 \%$ of the stomachs examined from a population in southern Tasmania. Guiler (1970) claimed that $S$. harrisii, especially younger animals, can climb trees. The femur of a ringtail possum found in the scats was from a young animal, possibly taken from a nest. However these animals may be killed on the ground. An individual was seen in the study area crossing a creek via a road bridge.

Although sample sizes in the present study are small, the categories of prey included in the diet of the species examined are in accord with that found by others in more extensive studies in other areas. It is thus considered that comparisons between the species are justified. The three species for which data were obtained were found to overlap most in their use of small mammals (i.e. Rattus lutreolus, Pseudomys higginsi, and Antechinus spp.). However each species had a major component of the diet (i.e. $S$. harrisii, large mammals; Felis catus, birds; D. viverrinus, invertebrates and plant material) which was not utilized by the other species. The habitat preferences of $D$. viverrinus also differed from that of the other carnivores (Taylor et al. 1985). Hence it is unlikely that substantial competition for food was occurring between these species. No data on the diet of $D$. maculatus were obtained. Edgar (1983) and Godsell et al. (1984) reported that their diet included birds, rats and other small terrestrial and arboreal mammals. This is a diet which is similar to that found for $F$. catus in this study. The habitat preferences of $D$. maculatus and F. catus were also found to be similar (Taylor et al. 1985). It is thus possible that competition could occur between the native $D$. maculatus and the introduced feral cat. More detailed research on the effects of feral cats on the native fauna is obviously warranted. 


\section{ACKNOWLEDGEMENTS}

Traps were lent by the Tasmanian National Parks and Wildlife Service. Drs A. Richardson, $\mathrm{J}$. Madden and $\mathrm{H}$. Willia ms identified invertebrate remains. Field work was funded by the HydroElectric Commission and the Forest Ecology Research Fund. Prof. D.M. Stoddart and $\mathrm{Mr}$ D. Pemberton commented on a draft of the manuscript.

\section{REFERENCES}

BLACKHALL, S., 1980:Diet of the eastern native-cat, Dasyurus viverrinus (Shaw), in southern Tasmania. Aust. Wildl. Res. 7: 191-197.

BRUNNER, H. \& COMAN, B.J., 1974: THE IDENTIFICATION OF MAMMALIAN HAIR. Inkata Press, Melbourne.

BRUNNER, H., STEVENS, P.L. \& BACKHOLER, J.R., 1981:Introduced mammals in Victoria. Vict. Natur. 98:5-17.

BUCHMANN, O.L.K. \& GUILER, E.R., 1977: Behaviour and ecology of the Tasmanian devil, Sarcophilus harrisii. In STONEHOUSE, B. \& GILMORE, D. (Eds): BIOLOGY OF MARSUPIALS. University Park Press, London: $155-168$.

EDGAR, R., 1983: Spotted-tailed quoll, Dasyurus maculatus. In STRAHAN, R. (Ed.): COMPLETE BOOK OF AUSTRALIAN MAM$M A L S$. Angus and Robertson, Sydney: 18-19.

GODSELL, J., 1983: ECOLOGY OF THE EASTERN QUOLL, DASYURUS VIVERRINUS, (DASYURIDAE: MARSUPIALIA). Unpubl. Ph.D. thesis, Australian National University.
GODSELL, J., ARNOLD, J., MAISEY, K., MAN. SERGH, I. \& BEGG, R., 1984: Quolls. Aust. Nat. Hist. 21: 250-255

GREEN, R.H., 1967: Notes on the devil (Sarcophilus harrisii) and the quoll (Dasyurus viverrinus) in north-eastern Tasmania. Rec. Queen Vict. Mus. 27: $1-13$.

GREEN, R.H., 1973: THE MAMMALS OF TAS$M A N I A$. The a uthor, Launceston.

GUILER, E.R., 1970:Observations on the Tasmanian devil, Sarcophilus harrisii (Marsupialia : Dasyuridae). I. Numbers, home range, movements and food in two populations. Aust. J. Zool. 18: 49-62.

GUILER, E.R., 1983: Tasmanian devils - Australia's ugliest marsupials. Aus, Nat. Hist. 21: 116-119.

HOCKING, G.J.\& GUILER, E.R., 1983: The mammals of the Lower Gordon River Region, south-west Tasmania. Aust. Wildl. Res. 10: 1-23.

JONES, E. \& COMAN, B.J., 1981: Ecology of the feral cat Felis catus (L.), in south-eastern Australia. I. Diet. Aust. Wildl. Res, 8: 537-548.

TAYLOR, R.J., 1985: Identification of the hair of Tasmanian mammals. Pap. Proc. R. Soc. Tasm 119:69-82

TAYLOR, R.J., BRYANT, S.L., PEMBERTON, D. \& NORTON, T.W., 1985: Mammals of the Upper Henty River Region, western Tasmania. Pap. Proc. R. Soc. Tasm. 119: 7-14.

THOMSON, J.A. \& OWEN, W.H., 1964: A field study of the Australian ringtail possum, Pseudocheirus peregrinus (Marsupialia : Phalangeridae). Ecol. Mono. 34: 27-52.

(accepted Dec, 9, 1985) 